
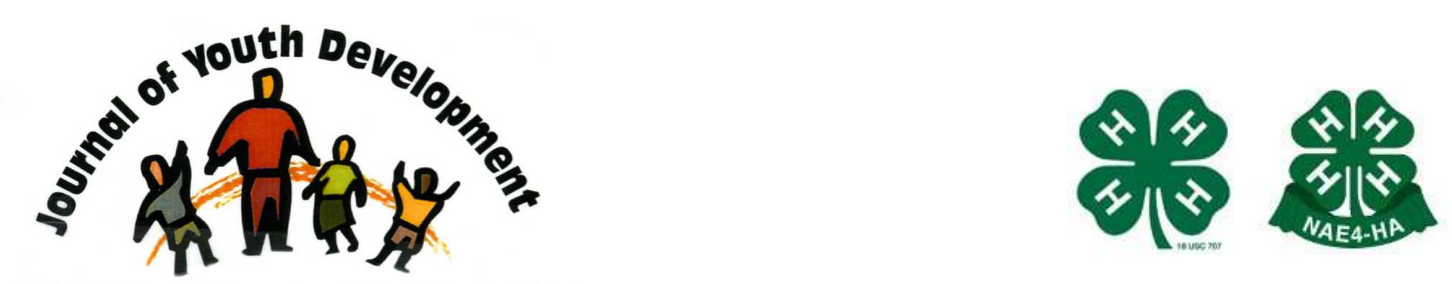

Bridging Research \& Practice

\title{
Civic Engagement in Adolescents: Engendering Civic Awareness Through a University Youth Program
}

\author{
Jennifer S. Parker \\ Department of Psychology \\ University of South Carolina Upstate \\ Spartanburg, SC \\ jparker@uscupstate.edu \\ Timothy M. Dale \\ Department of Social Change and Development \\ University of Wisconsin Green Bay \\ Green Bay, WI \\ Kerri-Ann G. Wilkins \\ University of South Carolina Upstate \\ Spartanburg, SC
}




\title{
JOURNAL OF YOUTH DEVELOPMENT \\ bridging research and practice

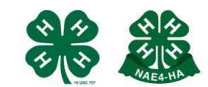

Bridging Research \& Practice

Volume 5, Number 1, Spring 2010

Article 100501FA001

\section{Civic Engagement in Adolescents: Engendering Civic Awareness Through a University Youth Program}

\author{
Jennifer S. Parker and Kerrie-Ann G. Wilkins \\ University of South Carolina Upstate \\ Timothy M. Dale \\ University of Wisconsin Green Bay
}

\begin{abstract}
A weeklong residential Youth Leadership Institute Project was conducted at USC Upstate to promote essential skills deemed necessary for future civic engagement and political identity. The program and curriculum followed a framework that suggests that underlying civic skills are necessary to foster civic engagement among youth. Building on this theory, this reported study illustrates that civic engagement requires a developmental and educational process. Adolescence is a primary time for identity exploration and formation, which makes this stage an optimal time to engender civic awareness. A diverse group of 49 youth ranging in age from 14 to 17 participated. Results from the project demonstrate that when evaluating the significance and success of youth civic engagement programs, an account must be made for both the developmental and educational capacities. In pursuing projects such as ours on university campuses and beyond, psychologists and political scientists should work together to measure their outcomes in terms of these variables.
\end{abstract}

\section{Introduction}

The decline of civic engagement is well documented by political scientists. Research explaining this decline is usually motivated by an interest in determining how civic life can be revitalized. If democratic society requires an engaged citizenry, and civic engagement is on the decline, then as advocates of democracy we are committed to finding ways to renew civic involvement. Our next step as scholars has thus involved pursuing research and avenues for civic re-engagement. This problem and project seems most important among youth, who are classically and increasingly disengaged, but who will shape the landscape of future civic life. In fact, as 
traditional civic bonds are eroded, youth will either need to acquire and cultivate new bonds, or we risk an even greater decline in civic engagement among this demographic.

Though civic engagement is in decline (Putnam, 1996, 2000), several avenues can be pursued to address this decline. One significant avenue regards civic engagement among youth, since it has been shown that engendering civic roots in adolescent years strongly correlates to citizenship in adulthood (Mannheim, 1952). This can be accomplished in several ways, including actively involving youth in community affairs (Evans \& Prilleltensky, 2007; Flanagan, 2003a), organized activities in schools (Verba, Schlozman, \& Brady, 1995), and in volunteer programs that emphasize a collectivist way of achieving goals (Kirlin, 2002). Flanagan (2003b) argues that an 'appreciation for polity' develops in adolescents as they participate in these organizations and activities. In addition, these activities help to foster a sense of belonging and an awareness of being part of a community. Thus, civic activities help adolescents develop elements of a civic identity that will expand civic engagement into the future. Programs that engage youth in the community not only contribute to a thriving community but also to the development of that young person (Harré, 2007).

We presuppose this research, and understand that organized youth activities exploring social problems within the broader community facilitate the development of a broader social understanding and provide a rich context for development of political identity. These activities promote a greater understanding of the self in a world context leading to the formation of values that include a greater responsibility to society, and to the development of essential skills necessary for civic engagement.

Prior research in youth development has focused more on risky behavior of youth and costs of these risks to the individual and to society. In recent years some social theorists have begun to view youth as community assets and focus on youth engagement in the community. This approach focuses on development of skills that aid in identifying, analyzing and acting on issues relevant to youth. In this model, adults do not necessarily assume the lead in organized youth activities; rather they mentor and facilitate opportunities for youth to lead (Watts \& Flanagan, 2007).

Given the research indicating a decline in civic engagement and evidence that this decline can be addressed, we believe that an additional responsibility of scholars, and the wider academic community, is to pursue initiatives to revitalize civic engagement among youth. Universities are uniquely equipped with resources that can promote engagement in communities. If applied correctly, initiatives utilizing these resources will allow us to apply and test civic engagement research, and better understand the civic skills and knowledge to increase the propensity of youth to be civically engaged.

The present youth leadership project provides a university setting where youth can identify relevant issues in their community and the world, and apply critical analysis to problem solving under the leadership of University professors in Psychology and Political Science. This method is expected to foster development of essential skills needed for future civic engagement and political identity.

\section{Developmental characteristics needed for civic engagement}

From a developmental perspective, adolescence is an optimal time to learn skills that facilitate civic engagement. At this stage in the lifespan, youth are actively engaged in the process of identity exploration and formulating a cohesive identity, which involves a deeper understanding 
of self, social relationships and society, and deciding which values held by society, will be accepted as one's own (Erikson, 1968).

Developmental psychologists in recent decades have moved from a focus on individual growth to an emphasis on the contextual influences on development (Bronfenbrenner, 1979). Thus civic involvement becomes an important context for consolidating an identity that includes political/civic development. The inclusion of civic engagement in youth programs incorporates greater social responsibility and political values into the identity process and contributes to positive social relationships (Flanagan, 2003a).

Several characteristics of development underlie the formation of skills necessary for civic engagement. One of these characteristics is a level of identity formation that includes a connection to society. Hansen, Larson and Dworkin (2003) investigated the types of developmental experiences related to five categories of youth activities. These authors utilized the Youth Experiences Survey (YES) (Hansen \& Larson, 2002) to assess the impact of youth activities. They found higher rates of learning experiences reported in youth activities when compared to time in school or time spent hanging out with friends. Youth participating in these activities reported high rates of personal development in the area of identity exploration, identity reflection, leadership and linkage to community when compared to youth involvement in academic activities, sports, or performance and fine arts.

Another characteristic according to Flanagan (2003b) that directly correlates to civic engagement is trust. Flanagan defines trust as "the belief that others are fair, that they will not take advantage of us, although they could." Trust is the product of having a sense of security in infancy. This feeling is then nurtured by our environments and caregivers and evolves into individuals having a trustworthy disposition. Erickson (1968) deemed this trait as fundamental to the development of a healthy individual. Accordingly, Putnam (2000) describes trust and civic engagement as a "virtuous cycle," that is, each emphasizes the other. He further states that, involvement in volunteering is carried out by those who trust others and this participation increases trustworthiness. Flanagan (2003b) also found that adolescents who were engaged in their community had higher levels of trust than their disengaged cohorts. She concludes by stating that fostering social trust is a source of civic hope and engagement.

According to Larson (2000), initiative is a necessary characteristic for positive developmental experiences such as leadership and civic engagement. He analyzed positive youth development across several contexts and focused on the development of initiative, which requires intrinsic motivation, concerted engagement in the environment, and effort directed toward a goal. Larson reports that organized voluntary youth activities provide a more fertile context for the development of initiative when compared to school experience and social experience with friends. Therefore, organized youth activities may be especially suited for the development of civic engagement.

\section{Underlying civic skills and essential civic capacities}

Political scientists and psychologists have identified key roots of civic engagement among youth, and the skills required to facilitate and sustain this engagement. One such study by Youniss and McLellian (1997) proposes that involvement in civic organizations will have a two-fold impact on adolescents. To begin with, it familiarizes youth to the organizational practices needed for adult civic engagement and this involvement now aids in civic engagement being integrated into their identity. In adhering to the policies of their organizations, adolescents are introduced to one of the principal skills needed for civic engagement in adulthood. Kirlin (2002) states that 
involvement in organizations results in the development of necessary civic skills, they include working in groups, organizing others to accomplish tasks, communicating and working out differences. Service brings about awareness that society is the result of human actions, whether political or moral. In addition, it dispels the idea that adolescents are too young to cause a change. To ensure that adolescents engage in civic skill building activities, Kirlin (2002) suggests that minor modifications need to be made to programs. Instead of telling them of society's problems and ways to fix them, facilitate students in identifying these problems and allowing them to come up with solutions to alleviate them. Kirlin (2002) states that by these minor restructuring, youth acquire such skills as: "voicing one's opinion, expressing interest, and reaching consensus about an action."

Understanding the development of these underlying skills, however, does not fully account for the ways in which civic engagement is cultivated among youth. The development of these skills also requires the development of certain 'civic capacities,' which facilitate the broader development of the underlying civic skills identified by Kirlin. We divide civic capacities into two categories - developmental capacities and educational capacities. Developmental capacities are those psychological and social capacities through which civic skills themselves are realized. Educational capacities refer to the basis of knowledge and social understandings that are required in order to develop and practice broader civic skills. Previous civic engagement research emphasizes the importance of the development of civic skills, particularly in adolescence, but does not sufficiently account for the underlying capacities that these skills require and assume.

As we consider the significance of civic capacities for the development of civic skills, we find helpful the categories Kirlin describes: monitoring events, deliberating about policy issues, interacting with others to promote interests, and influencing policy decisions. According to Kirlin, these civic skills each require a number of underlying skills (see Table 1 ). These underlying skills are insufficient, however, without other substantive developmental and educational goals also being attained. The underlying skills identified by Kirlin in the second column of the chart presented in Table 1 almost all involve understanding and processing issues and perspectives. Without these understandings, it is difficult or impossible to engage in the overarching civic processes identified in the first column of the chart. It is important to notice, however, that the underlying civic skills rely on civic capacities that make possible the civic understanding and processing that are needed to practice civic skills.

The first civic skill identified is the practice of monitoring public events and issues. As Kirlin describes, this skill requires that citizens be able to understand the distinctions between sectors of society, understand the context for events and issues, and acquire and thoughtfully review the news. These requirements are possible only when developmental and educational opportunities have been available to citizens in formative stages of life. In order to understand the context of political events and thoughtfully review the news at this level, for example, citizens must understand the nature of the political community. That is, citizens can only properly process the news if they comprehend the political world and the problems that they face within it. Without a context for understanding news and events, and how these things affect their lives, citizens will either misunderstand or ignore the most critical elements of this information. Additionally, monitoring public events and issues involves understanding not only the sectors of society but also the levels of citizenship - local, national, and global. Citizens need to be able to situate themselves within a community in order to comprehend the way in which its news and events relate to them. 
Developmentally speaking, adolescents are actively exploring their identity, acquiring a deeper understanding of self as a separate being from parents and societal models, and beginning to make decisions about how they fit into the greater social context. Increasing their opportunities to monitor and participate in public events contributes not only to the process of individual identity attainment but also increases a sense of belonging to a group. This provides a broader context for the individual to explore how they fit into the larger community.

Deliberating about public policy issues is the second civic skill identified by Kirlin. To do this, Kirlin argues, citizens must be able to think critically about issues, understand multiple perspectives, and understand democratic society. This thinking and understanding also calls for the educational capacity to understand complex problems and policy issues, as well as a familiarity with democratic institutions and deliberative procedures. In addition to an appreciation for multiple perspectives, civic engagement also involves knowing the methods and goals for reaching agreement.

Adolescents are moving from a concrete stage of thinking to a higher level of decision-making, critical thinking and abstract reasoning. Providing activities for adolescents to identify issues, and to discuss and debate multiple aspects of those issues, will advance their reasoning ability and understanding of complex social issues.

Interacting with others to promote personal and common interests is the third civic skill that has been identified. Kirlin rightfully suggests that this skill involves an acceptance of the norms of collective decision-making, and the ability to work with others to define a common objective and a work plan to achieve this objective. The ability to articulate individual and group interests, however, demands that underlying cognitive capacities already exist so that these can be appropriately expressed and acted upon. One must be able to identify individual and community interests, as well as be aware that individual and group interests might potentially conflict. It is only through a deeper understanding of the realities of diversity that a cognitive flexibility will exist that allows for compromise in collective decision-making.

During adolescence, peers are influential and adolescents develop more intimate and meaningful connections to each other. Development of these interpersonal skills along with a greater capacity to reason gives way to acquisition of leadership skills such as trust and teamwork. As they develop trusting relationships, collective decision-making becomes more likely, along with a greater understanding of democratic society.

The final civic skill identified is the ability to influence policy decisions on public issues. As the most advanced civic skill, this is what allows individuals to affect social change through civic engagement. As Kirlin describes, the ability to identify decision-makers and institutions, and understanding appropriate vehicles for influencing decisions, are important related underlying skills. Educationally speaking, influencing policy decisions on public issues also demands an acquaintance with channels of decision-making, and knowing how and where to contact public officials. This also involves knowing which messages are appropriate for particular political channels and civic activities.

Developmentally speaking, adolescents are capable of understanding multiple perspectives of issues and reasoning well. They increase these capacities when they participate in activities that foster decision-making. Incorporating opportunities for adolescents to meet with public officials and provide input on policy decisions instills a political identity into their understanding of self and contributes to the development of a political ideology. Organized youth programs such as 
the one described in this paper provide a unique opportunity for positive developmental experiences that underlie development of civic skills and future civic engagement.

\section{Methods}

\section{Description of program, activities, civic skills, civic knowledge}

The Youth Leadership program and curriculum followed Kirlin's framework (2002), which suggests that underlying civic skills are necessary to foster civic engagement among youth. We find that these developmental skills are cultivated even more successfully when practiced in the context of civic activities that include the transmission of civic knowledge. For example, awareness of community problems, knowledge of the avenues for addressing these problems, and appreciation of the efficacy of specific solutions all essentially contribute to the increased likelihood that youth will become civically engaged. Building on this theory, our case study illustrates that civic engagement requires a developmental and educational process. Scholars and university communities can offer productive contributions to this process through programs such as youth leadership project presented in this paper.

The Youth Leadership Summer Institute was a weeklong residential workshop carried out at the University of South Carolina Upstate. A Housing and Urban Development Community Outreach Partnership Center Grant funded the Youth Leadership Institute designed to engage disadvantaged youth from Spartanburg's Southside into the community and provide an opportunity structure for leadership development. Prior research indicates that disadvantaged youth have fewer opportunities for community involvement. This may be due to a lack of resources in disadvantaged communities to develop and sustain programs. Furthermore, the families of these youth are less likely to model civic involvement (Watts \& Flanagan, 2007). This pattern is demonstrated in adulthood with less civic engagement in disadvantaged groups.

\section{Participants}

A total of 49 participants ( 25 males, 22 females) were selected from 6 different high schools in Spartanburg County and from a girl's school in South Africa. The ages ranged from 14-17 with a mean age of 15.9. Of the 49 students selected, 26 were African American, 17 Caucasian American, 2 Asians, 2 of mixed ethnicity, and 2 South Africans ( 1 black and 1 white). Recruitment and inclusion of underserved youth from the Southside of Spartanburg was a priority goal of the program. Approximately half of the participants that were selected met the geographic criteria.

Overarching program goals were enhancing the identity process through increasing social understanding from local and global perspectives and teaching civic skills necessary for engagement. Another primary goal was to empower the youth to see themselves as agents of change. One of activities generated awareness and discussion of local and global problems that impact the present and future of the youth. By devising solutions that could be implemented now, the notion that they were too young to make a difference was dispelled. The youth were divided into groups at the inception of the program that reflected a wide range of diverse backgrounds. They carried out most of the activities in these groups; this was designed to promote teamwork and collective identity formation.

According to Flanagan (2003), meaningful connections to others assists with the formation of a collective identity which in turn leads to lifelong civic participation. To that end, trust and team building activities were the focus in the early part of the week along with an interactive workshop on leadership and values. This was then followed up with activities that brought 
about awareness of issues in the local community as well as in the global community. One planned activity was a visit to an impoverished area of Spartanburg, where many had not previously traveled. This tour was led by a local politician who has spent his career researching the illegal disposing of waste and chemicals that took place in this community and the resulting health problems experienced by the residents. Another activity was a poverty simulation, where participants experienced food allocations relative to a worldview. Additionally, the youth engaged in an interactive videoconference with students from Pretoria Girls High School in South Africa, discussing similarities and differences in problems faced and solutions to mitigate them.

\section{Results}

Table 1 is an expansion of Kirlin's (2002) framework. The first two columns in the table represent Kirlin's framework. In addition to civic skills and underlying skills presented by Kirlin's, we feel that more can be gained by engaging in community-organized activities. Along with civic skills and underlying civic skills, adolescents develop capacities that are vital component in engendering civic engagement in adulthood. As a result, we added two additional columns, and cited examples of how our program aided in gaining this civic development. Such examples are, awareness about diversity, and enhanced critical thinking. By gaining this development, civic engagement can now be incorporated into their identities and partaking in these activities will lessen the decline of civic engagement.

Researchers (Flanagan, 2003a; Kirlin, 2002) have observed that youth who participate in their adolescent years are more likely to become civically engaged in adulthood. We also believe that the acquisition of civic knowledge can further be divided into developmental and educational aspects. The civic knowledge one gains can facilitate cognitive and psychosocial development of the youth, such as learning teamwork, leadership skills and advancing critical thinking skills as well as furthering the educational success by increasing their understanding of world problems, politics and leadership. Self-report from all participants indicated growth in awareness of world problems and interest in solving these problems, and in areas of team building, awareness of diversity, political interest, and motivation to become more involved in the community. 
Table 1

Developing Civic Capacities in Youth

\begin{tabular}{|c|c|c|c|}
\hline Civic Skill & $\begin{array}{l}\text { Underlying } \\
\text { Skills }\end{array}$ & Civic Capacities & Program Activities \\
\hline $\begin{array}{l}\text { Monitoring } \\
\text { public } \\
\text { events and } \\
\text { issues }\end{array}$ & $\begin{array}{l}\text { Understand } \\
\text { distinctions between } \\
\text { three sectors of } \\
\text { society (public, } \\
\text { nonprofit and } \\
\text { private) } \\
\text { Understand context } \\
\text { for events and } \\
\text { issues (what } \\
\text { happens and why) } \\
\text { Capacity to acquire } \\
\text { and thoughtfully } \\
\text { review news }\end{array}$ & $\begin{array}{l}\text { Developmental } \\
\text { Facilitate identity development } \\
\text { by increasing } \\
\text { understanding of society that } \\
\text { leads to the development } \\
\text { of social values and a collective } \\
\text { identity } \\
\text { Educational } \\
\text { Increase awareness of } \\
\text { community identity and its } \\
\text { members } \\
\text { Expand knowledge of current } \\
\text { events } \\
\text { Differentiate between types of } \\
\text { communities (local, state, } \\
\text { national and international ) }\end{array}$ & $\begin{array}{l}\text { Tour an impoverished neighborhood } \\
\text { led by state congressional } \\
\text { representative. Specifically learned } \\
\text { about environmental racism, and } \\
\text { efforts to address related injustice. } \\
\text { Participate in a poverty simulation } \\
\text { lunch. } \\
\text { Attend lecture and discussion with } \\
\text { representative from } \\
\text { The World Bank. }\end{array}$ \\
\hline $\begin{array}{l}\text { Deliberating } \\
\text { about public } \\
\text { policy issues }\end{array}$ & $\begin{array}{l}\text { Think critically about } \\
\text { issues } \\
\text { Understand multiple } \\
\text { perspectives } \\
\text { on issues } \\
\text { Understand } \\
\text { democratic society }\end{array}$ & $\begin{array}{l}\text { Developmental } \\
\text { Enhance critical thinking and } \\
\text { facilitate formation } \\
\text { of ideology } \\
\text { Educational } \\
\text { Increase understanding of } \\
\text { public policy issues } \\
\text { Identify democratic processes } \\
\text { and institutions } \\
\text { Understand the goals and } \\
\text { methods of reaching political } \\
\text { compromise and agreement }\end{array}$ & $\begin{array}{l}\text { Public policy working groups } \\
\text { identified challenges, and ways to } \\
\text { address them at levels of local, } \\
\text { national, and international } \\
\text { governance. } \\
\text { Discussion of limited resources and } \\
\text { competition, including general } \\
\text { political concerns. Simulated } \\
\text { democratic deliberation about } \\
\text { allocating resources to different } \\
\text { groups. }\end{array}$ \\
\hline $\begin{array}{l}\text { Interacting } \\
\text { with other } \\
\text { citizens to } \\
\text { promote } \\
\text { personal and } \\
\text { common } \\
\text { interests }\end{array}$ & $\begin{array}{l}\text { Understand } \\
\text { democratic society } \\
\text { (collective decision } \\
\text { making as norm) } \\
\text { Capacity to articulate } \\
\text { individual } \\
\text { perspective and } \\
\text { interests } \\
\text { Work with others to } \\
\text { define common } \\
\text { objective } \\
\text { Create and follow a } \\
\text { work plan to } \\
\text { accomplish a goal }\end{array}$ & $\begin{array}{l}\text { Developmental } \\
\text { Facilitate leadership and social } \\
\text { skills through teamwork } \\
\text { Aid in the development of } \\
\text { political views that include civic } \\
\text { and community perspectives } \\
\text { Educational } \\
\text { Identify individual and } \\
\text { community interests } \\
\text { Increase awareness of potential } \\
\text { conflicts between individual and } \\
\text { group interests } \\
\text { Promote understanding of } \\
\text { diversity and increase cognitive } \\
\text { flexibility }\end{array}$ & $\begin{array}{l}\text { Participate in workshops on local and } \\
\text { global leadership. } \\
\text { Teambuilding activities to foster } \\
\text { group understanding, trust and } \\
\text { cohesion and completed personality } \\
\text { assessments to understand individual } \\
\text { differences. } \\
\text { Model UN debates addressing global } \\
\text { environmental concerns. } \\
\text { Videoconference with students } \\
\text { attending school in another country } \\
\text { (South Africa) to discuss similarities } \\
\text { and differences in political and social } \\
\text { issues. }\end{array}$ \\
\hline $\begin{array}{l}\text { Influencing } \\
\text { policy } \\
\text { decisions on } \\
\text { public issues }\end{array}$ & $\begin{array}{l}\text { Identify decision } \\
\text { makers and } \\
\text { institutions } \\
\text { Understanding } \\
\text { appropriate vehicles } \\
\text { for influencing } \\
\text { decisions }\end{array}$ & $\begin{array}{l}\text { Developmental } \\
\text { Foster a political identity } \\
\text { Educational } \\
\text { Become acquainted with } \\
\text { political officials and channels of } \\
\text { decision-making } \\
\text { Understand the impact of } \\
\text { political action on changes in } \\
\text { the community }\end{array}$ & $\begin{array}{l}\text { Meet with the local Mayor and } \\
\text { discussed political concerns in } \\
\text { community, and possible solutions to } \\
\text { these problems. } \\
\text { Scheduled meeting time with other } \\
\text { local representatives focusing } \\
\text { community problems and possible } \\
\text { solutions. }\end{array}$ \\
\hline
\end{tabular}




\section{Discussion}

The Youth Leadership Institute Program was a demonstration of the application of the research on youth civic engagement. Many researchers have argued that adolescents need an environment that will foster the growth of civic skills to engender citizenry in adulthood. In addition to achieving this, we examine the developmental and educational requirements for cultivating civic engagement. With this differentiation, program organizers will be able to gear their activities to facilitate the engendering of specific civic skills. We also hoped to provide a model for future applications of other university initiatives and programs that strive to cultivate civic engagement, as well as offer an avenue for future research, including the efficacy of such programs, follow-up research, tracking, and identifying successful and unsuccessful community outreach and youth civic engagement activities.

Projects such as ours should be pursued on university campuses, and psychologists and political scientists should work together to measure specific outcomes, which will lead to a greater understanding of ways to improve civic engagement among youth.

\section{Acknowledgements}

This project was funded through a Housing and Urban Development Community Outreach Partnership Center Grant and the USC Upstate Center for Undergraduate Research.

Civic Engagement in Adolescents: Engendering Civic Awareness through a University Youth Program.

\section{References}

Bronfenbrenner, U. (1979). The ecology of human development: Experiments by nature and design. Cambridge, MA: Harvard University Press.

Erickson, E.H. (1968). Identity: Youth and crisis. New York: W.W. Norton

Evans, S.D., \& Prilleltensky, I. (2007). Youth and democracy: Participation for personal, relational, and collective well-being. Journal of Community Psychology, 35, 681-692.

Flanagan, C. (April 2003a). Developmental roots of political engagement. PS: Political Science \& Politics. 36(2), 257-261.

Flanagan, C. (2003b). Trust, identity and civic hope. Applied Developmental Science. 73 ), 165171.

Hansen, D.M., \& Larson, R.W. (2002). The Youth Experience Survey. Unpublished manuscript, University of Illinois at Urbana-Champaign. http://web.aces.uiuc.edu/youth/

Hansen, D.M., Larson, R.W., \& Dworkin, J.B. (2003). What adolescents learn in organized youth activities: A survey of self-reported developmental experiences. Journal of Research on Adolescence, 13(1), 25-55.

Harré, N. (2007). Community service or activism as an identity project for youth. Journal of Community Psychology, 35, 711-724. 
Kirlin, M. (September 2002). Civic skill building: The missing component in service programs. PS: Political Science \& Politics. 35(3), 571-575.

Larson, R.W. (2000). Toward a psychology of positive youth development. American Psychologist, $55(1), 170-183$.

Larson, R.W., Hansen, D.M., \& Moneta, G. (2006). Differing profiles of developmental experiences across types of organized youth activities. Developmental Psychology, 42 (5), 849863.

Mannheim, K. (1952). "The problem of generations." In Essays in the Sociology of Knowledge. Trans. and ed. Paul Kecskemeti. New York: Oxford University Press, 276-322.

Patrick, J.J. (2000). Introduction to education for civic engagement in democracy. In Education for Civic Engagement in Democracy: Service Learning and Other Promising Practices. Ed. Sheilah Mann and John J. Patrick. Bloomington: Indiana University, ERIC Clearinghouse for Social Studies/Social Science education, 9-15.

Putnam, R.D. (1996). The Strange Disappearance of Civic America. The American Prospect, 7(24).

Putnam, R.D. (2000). Bowling alone: The collapse and revival of American community. New York: Simon \& Schuster.

Verba, S., Schlozman, K.L., \& Brady, H.E. (1995). Voice and Equality: Civic Voluntarism in American Politics. Cambridge, MA: Harvard University Press.

Watts, R.J., \& Flanagan, C. (2007). Pushing the envelope on youth civic engagement: A developmental and liberation psychology perspective. Journal of Community Psychology, 35(6),779-792.

Yates, M., \& Youniss, J. (1996). Community service and political-moral identity in adolescents. Journal of Research on Adolescence, 6(3), 271-284.

Youniss, J., \& McLellian, J.A. (1997). What we know about engendering civic identity. American Behavioral Scientist. 40(5), 620-631.

(C) Copyright of Journal of Youth Development Bridging Research and Practice. Content may not be copied or emailed to multiple sites or posted to a listserv without copyright holder's express written permission. However, users may print, download or email articles for individual use. 